\title{
Walking Our Talk About Assessment With Preservice Teachers
}

\author{
Elizabeth Munroe, Andrew Foran, Katarin MacLeod, Deborah Graham, Lisa Lunney-Borden, \\ and Anne Curry
}

St. Francis Xavier University

\begin{abstract}
In this reflective study, six members of a Faculty of Education implemented or adapted researchinformed assessment practices in their university Bachelor of Education teaching. These practices included aligning university course outcomes to assessment, separating achievement on university course outcomes from achievement of non-academic outcomes, collaboratively creating achievement indicators for provincial curriculum outcomes, co-constructing criteria with university students for assignments, setting up opportunities with university students for peer feedback before an assignment is submitted for marking, and administering and marking a test according to research-suggested practices. This article describes the implementation of these practices and analyzes the challenges and successes experienced as these teacher educators strove to model assessment practices that are expected of preservice teachers when they enter the profession. The primary goal of implementation was to increase congruence between teaching and practice in terms of assessment.
\end{abstract}

Keywords: assessment; preservice teacher learning; self-study 


\section{Walking Our Talk About Assessment With Preservice Teachers}

We, as members of a Faculty of Education at St. Francis Xavier University, along with our preservice teachers have questioned if we walk our talk regarding our assessment practices. Over the past two years, six of us who teach certain core courses within the Bachelor of Education (B.Ed.) program have met regularly to discuss, debate, and puzzle through how to implement or adapt research-informed assessment practices. The assessment practices we have begun to incorporate into our courses are: aligning course outcomes to course assessment, separating achievement of course outcomes from achievement of non-academic outcomes, having preservice teachers create achievement indicators for provincial curriculum outcomes, coconstructing criteria for assignments with preservice teachers, providing opportunities for peer feedback before assignments are submitted for marking, and administering and marking a test according to practices suggested in professional assessment literature. This article is a reflective exploration of our experiences to date, describing the assessment practices that we have incorporated into our preservice teacher education courses and discussing the successes and challenges of this work.

Our ongoing collaborative reflection on assessment has had two specific aims: first to support our preservice teachers' learning of the B.Ed. course content, and secondly, to increase preservice teachers' understanding of current K-12 assessment practices. As a corollary, we have observed that this research has led to improved common standards among various B.Ed. courses within our Faculty. Through this collaborative engagement, our own understanding of assessment, and of each others' practices, has increased and evolved.

\section{Describing our Context}

Our Bachelor of Education program lasts 2 academic years, and preservice teachers have completed a bachelor's degree prior to acceptance. At the time of the study, there were approximately 115 preservice teachers in each year of the program for a total of 230 candidates. The Faculty of Education is comprised of 17 full-time members engaged in a program approach (versus a series of courses resulting in a degree). As instructors, we planned many of our core courses together and taught the courses within the same time block. Common planning sessions and the annual program review allowed us to examine our program critically and deeply. Several of us perceived our assessment practices as incongruent with research and public school practice. We began to question how we could improve our assessment practices, achieve more consistency among courses, and emulate more closely school board practices and policies.

In implementing research-based assessment practices, we had three goals:

- to increase preservice teacher depth of understanding of assessment of and for learning,

- $\quad$ to mirror school board and provincial practices and policies, and

- to increase congruence between what we teach about assessment and what we practise. 
In the following sections, we will elaborate on these three goals, highlighting both research and professional literature that informs our practice and connecting the goals to our Nova Scotia context.

\section{Applying Assessment for and of Learning Strategies to Increase Preservice Teacher}

Learning The research in assessment for learning, or formative assessment, has made very strong claims that implementation of such practices will increase student learning (e.g., Black \& Wiliam, 1998; Wiliam, Lee, Harrison \& Black, 2004). Various authors have described the process of implementing specific assessment for learning strategies (Cooper, 2007; Davies, 2007; Stiggins \& Chappius, 2012). In examining this professional literature, we realized that we were not implementing many of these promising assessment practices within our courses. For example, we were not offering descriptive feedback, routinely sharing learning goals, or encouraging peer and self-assessment to improve learning. With the aim of increasing our preservice teachers' learning, we proposed to adopt or adapt such assessment strategies for use in our B.Ed. classes.

\section{Mirroring School Board and Provincial Practices and Policies}

Our second goal in changing our assessment practices has been to mirror the policies and practices of school boards and the provincial Department of Education. Our preservice teachers will be entering those contexts once they graduate, and we believe it is important for these future teachers to be well versed in the terminology and practices of those settings.

In recent years, the following Nova Scotia school boards have revised their assessment policies and practices to reflect the above cited professional literature: Annapolis Valley Regional School Board, 2005; Cape-Breton Victoria School Board, 2010; Chignecto-Central Regional School Board, 2011; Halifax Regional School Board, 2008; and the South Shore Regional School Board, 2007. The Nova Scotia Educational Leadership Consortium ${ }^{1}$ and various school boards have offered a number of large scale conferences and presentations on assessment.

The principal concepts used in school board policies and guidelines are assessment for learning, equated to formative and sometimes diagnostic assessment in the Nova Scotian context, and assessment of learning, equated to summative evaluation. These terms are used in this article since this language is most often heard and used in the Nova Scotia educational context that our preservice teachers will enter. ${ }^{2}$

The first three objectives of the Evaluation Services division of the Nova Scotia Department of Education (2011) are as follows: provide information to improve the quality of educational decision making; provide information to identify the needs of students so that they can be supported; and help teachers understand assessment principles and practices (Evaluation Services, 2011). These objectives can be seen to implicitly support the current focus on assessment of and for learning, as well as the need for improvement of teachers' assessment practices. 
In our experience, the understanding and implementation of assessment for learning practices - and the associated language-has been uneven in provincial schools. For example, during a workshop at a secondary school, participants requested clarification of such terms as “assessment for learning” and "descriptive feedback." Conversely, when one author used an assessment for learning process during a master's course in leadership, one class member (currently a teacher in the province) thanked the instructor for applying current assessment for learning strategies and for making the assignment criteria so clear.

The ongoing transition in assessment practices in schools has challenged us as teacher educators. During informal discussion, preservice teachers have revealed that they had not experienced the new practices during their 17-year apprentice-of-observation (Lortie, 2002). Furthermore, in many cases they had not witnessed these practices during their practicum. In effect, we are modeling and teaching assessment practices that have not yet been institutionalized in many schools where our graduates will teach, despite ongoing efforts by many of our educational partners to provide professional development in this area.

Even though a university is not bound by the Education Act or by school board policies, we have decided as teacher educators that we wanted to honour the policies and practices that our preservice teachers will have to enact once they are in service. In our courses, we have done this by using the terminology used within Nova Scotia and by adopting textbooks and resources (Davies, 2007; Stiggins, 2007; Stiggins \& Chappius, 2012) that endorse assessment strategies that have been promoted in our province.

\section{Increasing Congruence Between Our Teaching and Practice}

Our third goal in changing our B.Ed. assessment practices was to increase congruence between what we taught about assessment and what we practised when we assessed preservice teachers. We acted on the premise that providing congruence between our message and our actions by modeling research-informed practices, thus enabling the preservice teachers to experience these practices, would increase the likelihood of their use after graduation. Several researchers have supported this stance, writing about their efforts to model and enable preservice teachers to experience described practices (Buck, Trauth-Nare, \& Kaftan, 2010; Goos \& Moni, 2001; Mrazek, 2008).

\section{Methodology and Data Source}

One strong impetus for beginning this inquiry was the experience of disconnect by those of us who taught courses on assessment. The mantra of “do as I say and not as I do" felt increasingly inappropriate and ineffective. Others of us had come from school board leadership positions and were steeped in current assessment practice and policies; thus, the lack of congruence between emerging school-based practices and the university practices was unsettling. Four of the authors began this inquiry and two others joined the discussions as the year unfolded.

From September 2009 to March 2011, we engaged in weekly collaborative planning and reflection on our progress with the implementation of assessment of and for learning strategies in our classrooms. We recorded our perceptions of our progress towards meeting our goal of 
congruence between the professional literature and our university marking procedures. As Miller (1990) suggested, we were discussing improvement options to obtain excellence in practice. Along with Lunenberg, Korthagen, and Swennen (2007), we believed that "when teacher educators work together and question each other" they could create new insights and improve their instruction (p. 598).

Loughran's (2007) distinction between reflection and self-study has helped us situate our methodology. He described reflection as occurring at the beginning of the research process. Researchers identify a problem, "not necessarily an error or mistake in need of fixing, rather a situation that attracts attention, for a variety of reasons" (p. 45), which determines what is observed, attended to, and reflected upon. Next, researchers distance themselves from the problem, framing and reframing observations and reflections against different perspectives. The self-study process begins when researchers collaborate in articulating their knowledge of practice-their private theories-including any changes in perceptions and valuing. Finally, researchers test their learning in the public domain against current public theory.

In our process, we identified our problem and then framed and reframed during formal and informal meetings, often as we collaborated on the design of assignments for the various courses we taught. We relied on our prior experience as teachers and the professional literature. In a conference presentation (CSSE, 2011), we articulated our knowledge of practice, a process that Loughran (2007) associated with self-study (p. 50). However, our work remains to be situated in the public assessment research literature. We find it interesting that Black and Wiliam (2009) followed a similar process: a meta-analysis of research demonstrating the power of assessment for learning, confirmatory classroom research (Wiliam et al., 2004), and finally situating their empirical findings in pedagogical theory (Black \& Wiliam, 2009).

\section{Implementation of Initiatives}

As part of our intent to improve assessment practices, and through our collaborative discussions, six initiatives evolved. Each of these assessment strategies has aligned our practices closer to those stated in the professional literature and the policies and procedures of local school boards.

\section{Aligning Course Outcomes to Course Assessment}

When we began this change process, the courses that we were teaching had achievement outcomes, and carefully thought-out assignments, but we did not make obvious to our preservice teachers the link between these two features. Acting on the principles of backwards design (Wiggins \& McTighe, 2005) and modeling the planning framework of Davies (2007), we started to include an assessment plan in our course outlines (see Figure 1). Such a plan clearly demonstrated to our preservice teachers (and to us) that the assignments were designed to enable them to demonstrate their knowledge, skills, and understanding of course outcomes. The succinct plan aligned all the curricular, instructional, and evaluative features of the course. Because we, as teacher educators, have found this to be such a valuable planning tool, creating an assessment plan has become an assignment during the required course on assessment. 
One of the authors has declared that she will no longer create a course outline without an assessment plan. Many of us concur, as we have noticed that very few preservice teachers ask how their mark was determined. The Chair of our program (one of the authors) has commented, "As chair of the B.Ed. program, having a clear assessment plan in course outlines has made my life much easier. When preservice teachers come in to question grades and where their mark has come from, I just get out the plan.” Because an assessment plan includes clear learning targets and explicit assessment strategies and tools, how a mark is derived is usually clear. Also, these plans demonstrate how we have attempted to resolve the dilemma of separating marks for achievement of course outcomes from marks for non-academic outcomes.

\section{Separating Achievement on Course Outcomes From Achievement on Non-Academic Outcomes (Such as Professionalism)}

Over the past 10 years, in $\mathrm{K}-12$ schools across the country, a significant change regarding calculating students' marks has occurred. Based on the work of many assessment experts (e.g., O’Connor, 2009), educators have come to realize that a mark should reflect what that student knows and can do in terms of the course content. A student's work habits, personality, or other extenuating circumstances should not inflate or degrade a mark. Currently, many Nova Scotia school board guidelines direct teachers not to add bias to a student's mark by, for example, deducting points for late assignments, giving a zero for an unfinished assignment, or by awarding bonus points for homework completion.

In the Nova Scotia school system, educators track student work habits and citizenship characteristics, and consider them very important for success. However, such learner attributes are reported separately on the report card. In the university setting, it is still commonplace for student behaviour to influence a student's mark, for example, marks are deducted for late assignments. Our B.Ed. program has established additional, expectations for professional behaviour because faculty believed that the behaviours of preservice teachers should imitate the processes and expectations of a classroom teacher. For example, preservice teachers should arrive at class on time; attend every class or notify the instructor of an absence; communicate clearly; and present themselves professionally. Previously, these professional behaviours had resulted in lowered marks for the preservice teacher.

We understood that we were definitely not walking the talk in our B.Ed. courses in terms of separating achievement of course outcomes from achievement of non-academic outcomes. When we examined this issue, however, we realized that for a university student, only one mark appeared on the transcript for each course. No avenue existed to report a student's mark for the achievement of the course outcomes in one place and to report on other attributes elsewhere. What were we to do? Some of us felt strongly that professional behaviours were an essential component of the B.Ed. program and were reluctant to have no marks attached to these.

Figure 1 illustrates the way in which we have tried to solve this dilemma within the 100 points allotted for a course. We decided to allot $85 \%$ of the mark to the course outcomes and $15 \%$ of the mark to B.Ed. program outcomes (i.e., professional behaviours). Obviously, this approach did not exactly mirror the distinct separation of content achievement from behaviour attributes which is currently evident in the school system. However, we felt that we were at least 
trying to make the two contributors to a preservice teacher's mark evident to them and to us.

FALL Assessment Plan (The standards of practice for the teaching profession and the standards of behavior for the teacher (BEd Program ) will comprise the re maining $15 \%$ of the final mark for this course)

\begin{tabular}{|c|c|c|c|}
\hline Outcomes & $\begin{array}{l}\text { Strategy }(\text { Conversation }=C ; \\
\text { Product }=\mathrm{P} ; \text { Observation }=\mathrm{O})\end{array}$ & Evaluation Tool & Score \\
\hline GCO6, GCO3, GCO5 & $\mathrm{P} / \mathrm{C}$ & Excavation \#1 & $/ 20$ \\
\hline GCO1, GCO2, GCO3 & $P$ & Annotated Lesson Plan & $/ 30$ \\
\hline GCO 4, GCO2, GCO1 & C & Email & $/ 15$ \\
\hline GCO2, GCO5, & $P$ & Excavation \#2 & $/ 20$ \\
\hline GCO $1,2,3,4,5,6$ & C & Binder--beginning portfolio (PTT) & formative \\
\hline $\begin{array}{l}\text { BEd Program } \\
\text { Expectations }\end{array}$ & & & $15 \%$ \\
\hline $\begin{array}{l}\text { - Punctuality } \\
\text { - Attendance } \\
\text { - Communication } \\
\text { - Attitude } \\
\text { - Respect (cell phones, } \\
\text { BlackBerry etc.) } \\
\text { - Preparedness } \\
\text { - Participation }\end{array}$ & Observation/Conversation & $\begin{array}{l}\text { Anecdotal Records } \\
\text { Documentation }\end{array}$ & $\begin{array}{l}\text { TOTAL } \\
/ 100\end{array}$ \\
\hline
\end{tabular}

Figure 1. Assessment plan demonstrating link between course outcomes (GCOs) and course assignments (Davies, 2008). This plan also illustrates the separation of achievement of course outcomes from the achievement of non-academic outcomes (such as professional behaviours).

In the first year of implementing this system in several core courses, some of us found that we were much more aware of the two aspects of our preservice teachers' marks. Also, preservice teachers seemed much more cognizant of the importance of their professional behaviour and they understood when marks were deducted from the $15 \%$ allocation. Our system is not perfect, and there is ongoing discussion among faculty members about this, but we feel positive that the issue of what a student's mark actually represents (i.e., knowledge of course content or professional behaviour) is still in discussion.

\section{Collaboratively Creating Achievement Indicators for Student Curriculum Outcomes}

As faculty members who planned in teams and worked from identical course outlines, we came to agreement on course outcomes and assignments, and we worked carefully to create common assessment plans (see Figure 1). Nevertheless, we soon discovered that we needed further (and sometimes extensive) conversations about indicators of student success for course assignments and specific markers along the way to achievement of course outcomes (Stiggins, 2007). The process of collaboratively creating a description of the assignments in our course outlines, of agreeing upon marking criteria, and of creating rubrics and other marking schemes led to more clarity for us as instructors and thereupon to more consistency in the marking process within our classes and among common sections of our classes.

One of us applied this process to an assignment for preservice teachers in a core curriculum course. In previous years, preservice teachers had had trouble connecting teaching and assessment tasks to provincial student learning outcomes. It appeared that the provincial outcomes needed to be broken down into specific markers of achievement (similar to the process 
we ourselves had experienced, described above). For the assignment, preservice teachers unpacked provincial outcomes and identified the evidence needed to demonstrate achievement of those outcomes. This assisted preservice teachers in developing assessment tools that were aligned with curriculum expectations, allowing them to arrive at a common understanding of final criteria.

\section{Co-Constructing Criteria With Students for Assignments}

As professors, we provided clear descriptions of assignments in course outlines, explained expectations for assignments in class, and showed marking rubrics to preservice teachers in advance. However, we did not extensively involve our students in the assessment process, a strategy strongly connected to student success (Alberta Assessment Consortium, 2006). To remedy this gap in practice, some of us co-constructed assignment criteria with preservice teachers, using Davies’ (2007) process and terminology.

In our course outline, we provided a minimal description for the assignment. In class, we allotted time for preservice teachers to brainstorm "what counts for this assignment," or "what we need to do to receive an A for this assignment," as well as to distribute the marks to the various criteria for success (e.g., 50\% for analysis of the concept and $25 \%$ for summarizing the concept). This small group process focused attention on the specific expectations of the assignment. Some experienced frustration, perhaps due to lack of prior experience with being so involved in the assessment process. One preservice teacher was overheard to exclaim, "I wish she (the professor) would just tell us what to do; this is hard! I want to know the right answer."

Instructors correlated the suggestions and added their own guidelines (if preservice teachers had not considered some aspects of the assignment). When more than one instructor taught the same course, we exchanged co-constructed criteria and modified them further so as to create common criteria for all sections of the course. Thus, preservice teachers' suggestions were combined with instructors' considerations and not disregarded. This process resulted in a detailed assignment-marking scheme to which preservice teachers could refer to as they worked on the assignment. The instructor then adhered closely to the marking scheme when reading and judging the completed assignments.

It is important to point out that instructors have not involved preservice teachers in coconstruction of the criteria for every assignment in the course. The process is time-consuming, and for some assignments preservice teachers were not knowledgeable enough about the type of assignment to determine appropriate criteria. For the most part, however, the experience was successful and preservice teachers frequently commented: "The criteria are clear.”

\section{Setting up Opportunities for Peer Feedback Before an Assignment is Submitted for Marking}

The use of peer feedback is an assessment for learning strategy that has been highly recommended in the professional literature (Cooper, 2007; Davies, 2007). The efficacy of peer feedback is dependent on clear criteria for an assignment or task; learners cannot provide useful 
feedback if they are unsure of what success looks like. Additional essential components include coaching of students regarding honest, descriptive feedback and a well-organized process.

In four sections of our Principles and Practices course, we designed one assignment so that preservice teachers might benefit from peer feedback and might learn about how to implement this when they become teachers. For the assignment, preservice teachers rehearsed appropriate email communication skills between teacher and parent, teacher and administrator, and teacher and external community member. The instructors provided the three basic scenarios and three sample emails.

The process then unfolded as follows:

1. Preservice teachers were placed in base groups, of three to five students in an online setting, namely Blackboard ${ }^{\mathrm{TM}}$.

2. The instructors reviewed in class the purpose and content of the email to be composed.

3. Each preservice teacher wrote a first draft of the email and posted it onto the Blackboard discussion forum.

4. Other base group members provided written, specific feedback, via the Blackboard discussion forum.

5. Preservice teachers chose one email, taking the peer feedback into consideration, and submitted it to the instructor for marking.

For this assignment, instructors made a clear distinction between peer assessment (descriptive feedback and suggestions for improvement) and peer evaluation (determining a grade). Conversations with preservice teachers had revealed their frequent negative experiences with peer evaluation; for example, some had seen their marks influenced by popularity issues. The peer feedback process, used as an assessment for learning strategy in our classes, allowed preservice teachers to live through a more positive peer assessment process.

\section{Administering and Marking a Test According to Research-Informed Practices}

Testing is a challenging area within assessment. Because of this, as much as we worked with our preservice teachers to model and inform them of alternative assessment techniques, we also taught them how to write a variety of test questions.

In assessing the course, two of the authors gave a test that was rooted in course outcomes and current issues in assessment. The preservice teachers had an initial assignment with the material, for which the professors provided formative feedback. From there, the professors offered support before, during, and after the test, using strategies suggested in the Alberta Assessment Consortium's Refocus publication (2006).

Before the test, preservice teachers worked in groups to write different kinds of questions (e.g., multiple choice, true/false, short essay) on the content to be tested. Those questions made up the majority of the test. During the test, self-identified learners could benefit from 
adaptations, and extra time was available, if needed. Preservice teachers could rework their essay questions after marking if they want to improve their score.

Several preservice teachers, surprised by a test as part of their course mark, made comments such as: "You're not REALLY going to give us a test, are you?" and "B.Ed. programs are not supposed to believe in testing!" However, we believe that the process helped us, as instructors, achieve several purposes. We modeled the supports teachers can provide before, during, and after a test, and we enabled our preservice teachers to re-experience the reality of writing a test. They admitted their anxiety to us: "I can't believe how nervous I am about writing this!" And they demonstrated concern for their future students: "This brings back memories from when I was in school—how are we to help students who have test anxiety?”

\section{Successes, Challenges, and Questions}

The primary goal of this collaborative reflective study was to examine our progress towards walking the talk in assessment. It is our hope that changes in our assessment practices will lead to increased success for preservice teachers in B.Ed. course work, increased likelihood that preservice teachers will implement these strategies in their own classrooms, and increased knowledge and understanding of local and provincial policies and practices.

We find it challenging to provide preservice teachers with authentic experience of research-informed practices within the constraints of a university assessment system. As faculty members, we contend with pressures that include limited class time, large class sizes, and the time required to develop shared visions of purpose and rationale for our assessment changes. Despite the challenges, we have been successful in walking the talk, or practicing what we preach with several aspects of assessment of and for learning. At least half of our B.Ed. faculty has become involved in changing their assessment practices, and discussions about assessment have become frequent during B.Ed. program meetings with the intent of improving our practice for program consistency.

We remain concerned about the learning and transformation required to have preservice teachers adopt assessment practices that they have not experienced as public school students or during practicum. We ask ourselves if preservice teachers' experience of research-based assessment practices during their B.Ed. program will cause them to implement these practices in their own classrooms, as teachers. Will this enable them to overcome their apprenticeship-ofobservation (Lortie, 2002)?

White (2010) suggested that modeling of a practice by teacher educators does not imply buy-in and/or transfer to future teaching. Swennen, Lunenberg, and Korthagen (2008) encouraged teacher educators to move beyond practicing what they preach to "preach what you teach” (p. 531). They suggested that making the modeling explicit may enhance the learning of preservice teachers. Lunenberg et al. (2007) found that teacher educators must also link their practices with theory. Are we being explicit enough about our modeling? Are we adequately linking our modeling to theory? 
Russell and Bullock (2010) challenged teacher educators to "help teacher candidates enact rather than consume educational experiences” (p. 20). In our work on assessment practices, we have moved towards enabling preservice teachers to experience, or consume, the strategies as students. We do encourage them try some of the strategies during practicum placements, and as we supervise them in their placements, we try to support their enactment of the strategies.

We believe that future research into preservice teachers' perceptions of assessment of and for learning as implemented within a B.Ed. program, and the perceived benefits, challenges, and tensions as they implement their learning in their practicum would be beneficial. As well, a longitudinal study, in which graduates who have experienced assessment of and for learning in the B.Ed. program are contacted to gather stories of their assessment practices as teachers, would expand understanding in this area.

\section{Significance of the Study}

Across Canada and around the world, administrators and teachers are learning about new assessment practices. Locally, school boards are encouraging or mandating changes, reflecting the extensive evidence of the potential for increased student success when those practices are implemented. Schools expect preservice teachers to be ready to implement new assessment practices in their own classrooms. There is even some expectation and hope that B.Ed. graduates will lead the implementation of new assessment practices because of their recent exposure to them in their B.Ed. program (Chair of B.Ed. program, personal communication, November 9, 2010).

Through our work, we have tried to send the following messages to our preservice teachers:

1. You are achieving more highly because of our assessment practices.

2. You are experiencing these assessment practices, not just hearing us describe them.

3. You are hearing and experiencing congruency between your B.Ed. classes and the schools where you will teach.

If we put all these three together, perhaps these students will implement effective assessment practices for the sake of their own students' success! 


\section{References}

Alberta Assessment Consortium. (2006). Refocus: Looking at assessment FOR learning (2nd ed.). Edmonton, Canada.

Annapolis Valley Regional School Board. (2005). Annapolis Valley Regional School Board student assessment, evaluation, and reporting practices and procedures. Retrieved from http://www.avrsb.ca

Black, P.,\& Wiliam, D. (1998). Inside the black box: Raising standards through classroom assessment. Phi Delta Kappan, 80(2), 1-20.

Black, P., \& Wiliam, D. (2009). Developing the theory of formative assessment. Educational Assessment, Evaluation and Accountability 21(1), 5-31.

Buck, G.A., Trauth-Nare, A.,\& Kaftan, J. (2010). Making formative assessment discernable to pre-service teachers of science. Journal of Research in Science Teaching, 47(4), 402-421.

Cape Breton-Victoria Regional School Board. (2010). Assessment primer 2010-2011. Retrieved from http://www.cbv.ns.ca

Chignecto-Central Regional School Board. (2011). Chignecto-Central Regional School Board guidelines for classroom assessment, evaluation, and reporting policy/procedures. Retrieved from http://www.ccrsb.ca

Cooper, D. (2007). Talk about assessment: Strategies and tools to improve learning. Toronto, Canada: Thomson Nelson.

Davies, A. (2007). Making classroom assessment work (2nd ed.). Courtney, Canada: Connections Publishing.

Davies, A. (2008). Preparing for a new year: Building an assessment plan. Courtney, Canada: Connections Publishing. Retrieved from http://annedavies.com/PDF /School_Year_Plan.pdf

Earle, L.M. (2003). Assessment as learning: Using classroom assessment to maximize student learning. Thousand Oaks, CA: Corwin Press.

Evaluation Services, Nova Scotia Department of Education. (2011). Our objectives. Retrieved from http://plans.ednet.ns.ca/

Goos, M., \& Moni, K. (2001). Modelling professional practice: A collaborative approach to developing criteria and standards-based assessment in pre-service teacher education courses. Assessment and Evaluation in Higher Education, 26(1), 73-88.

Halifax Regional School Board. (2008). Assessment, evaluation, and communication of student learning: Policy and procedures. Retrieved from http://www.hrsb.ns.ca 
Lortie, D.C. (2002). Schoolteacher: A sociological study (2nd ed.). Chicago: University of Chicago Press.

Loughran, J. (2007). A response to "Reflecting on the self.” Reflective Practice, 7(1), 43-53.

Lunenberg, M., Korthagen, F., \& Swennen, A. (2007). The teacher educator as a role model. Teaching and Teacher Education, 23(5), 586-601.

Miller, J.L. (1990). Creating spaces and finding voices: Teachers collaborating for empowerment. Albany, NY: State University of New York Press.

Mrazek, R. (2008). Lessons learned from modeling emerging technology integration practices for pre-service and practicing teachers. In J. Luca \& E. Weippl (Eds.), Proceedings of World Conference on Educational Multimedia, Hypermedia and Telecommunications 2008 (pp. 424-430). Chesapeake, VA: AACE.

Nova Scotia Educational Leadership Consortium. (2011). About the NSELC. Retrieved from http://nselc.ednet.ns.ca/

O’Connor, K. (2009). How to grade for learning K-12 (3rd ed.). Thousand Oaks, CA: Corwin Press.

Russell, T., \& Bullock, S. (2010). From talk to experience: Transforming the preservice physics methods course. Brock Education, 20(1), 19-33.

South Shore Regional School Board. (2007). Student assessment and communication of student learning: Policy and procedures. Retrieved from http://www.ssrsb.ca

Stiggins, R. (2007). New mission, new beliefs: Assessment for learning [DVD]. Portland, OR: Educational Testing Service.

Stiggins, R., \& Chappius, J. (2012). An introduction to student-involved assessment FOR learning. Boston: Pearson.

Swennen, A., Lunenberg, M., \& Korthagen, F.(2008). Preach what you teach! Teacher educators and congruent teaching. Teachers and Teaching, 14(5), 531-542.

Wiliam, D., Lee, C., Harrison, C., \& Black, P. (2004). Teachers developing assessment for learning: Impact on student achievement. Assessment in Education: Principles, Policy and Practice. 11(1), 49-65.

White, E. (2010). Working towards explicit modeling: Experiences of a new teacher educator. Professional Development in Education. doi: 10.1080 /19415257.2010.531628

Wiggins, G. P., \& McTighe, J. (2005). Understanding by design. Alexandria, VA: ASCD. 


\section{Endnotes}

${ }^{1}$ The Nova Scotia Educational Leadership Consortium is a partnership among school boards, Mi'kmaw Kina'matnewey, Nova Scotia Teachers Union, Nova Scotia Department of Education, and universities offering teacher education programs. It provides professional development for educational leaders, aspiring leader, and classroom teachers, including prospective coaches and mentors. (Nova Scotia Educational Leadership Consortium, 2011).

2 The authors recognize that a third concept, assessment as learning (Earle, 2003), is current in other Canadian educational contexts. While the Department of Education has sponsored workshops on this concept, it is usually subsumed under the term assessment for learning. 